Reading and Writing Skills' Integration: a Process Writing Based Approach (PWA)

Karima Mohamed El Sayed

Reading and Writing Skills' Integration: a Process

Writing Based Approach (PWA)

Karima Mohamed El Sayed

Karimash2002@yahoo.com 


\section{Reading and Writing Skills' Integration: a Process \\ Writing Based Approach (PWA)}

\section{Karima Mohamed El Sayed}

This article discusses how the process writing approach can integrate between reading and writing skills. Furthermore, it highlights the stages and steps of writing as a process rather than as a product. It also discusses the writing skill, different stages of the process writing approach, and how process writing approach entails reading writing skills' integration in its various stages.

Writing , according to Gaith (2004), is a complicated process in which the writer shifts all thoughts, ideas, and attitudes to be visible and concrete. This indicates that the process of writing is a translation of what is cognitive to composed form of letters, words, and phrases. Writing is not simply a way for students to demonstrate what they know. According to the National Commission on Writing NCW in America's Schools and Colleges (2003, p. 13), It is "a way to help them understand what they know, at its best, writing is learning". In this view, to write is to communicate and interact.

Writing is a tool to express the spoken language through codes of symbols and signs through (vocabulary, grammar and semantic) .There are many simple writing content area activities that teachers can include to explain students how to write by comparing ,giving examples, explain concepts, make lists, or to write summaries and paraphrases. According to the National 


\section{Reading and Writing Skills' Integration: a Process Writing Based Approach (PWA)}

\section{Karima Mohamed El Sayed}

Commission on Writing in America's schools and colleges (2003, p.47), "Writing is how students connect the dots in their knowledge, for students writing is a key means of asserting and defending claims, showing what they know about a subject, and conveying what they have experienced ,imagined ,thought ,and felt". Writing in this view is a "process" that integrates various stages and sequences.

The practice of writing has long been linked to cognition. Writing is regarded as not only a means of communication and assessing understanding of content, but a process of constructing knowledge (Wooley, 2007). In this view, Bae (2011) showed that through English writing classes, explaining writing process and its features improve students' abilities to implement the task successfully. Students are likely to reflect better writing performance extends through their feedback on the writing process reports. After this review of writing, the following paragraphs discuss the writing process as an approach.

The writing process involves several stages; a typical sequence is comprised of three steps: prewriting, drafting, and, revising. Some sequences, however, there is another sequence such as thinking, planning, writing, and editing, while others use five steps, prewriting, drafting, revising, editing, and evaluating. In other

العدد الرابع




\section{Reading and Writing Skills' Integration: a Process Writing Based Approach (PWA)}

\section{Karima Mohamed El Sayed}

words, each writer has a preferred way of approaching the writing process, from simpler to more complex depending on the level of the learners, and the purpose of writing.

In this view, Clandinin \& Connelly (2002) noted that for the process writing approach teachers do not claim to model or answer questions, It focuses on fluency rather than accuracy. The process proposes motivation through various stages that the student is attentive to fulfill each stage to move to the other successfully. In addition it draws the main plan to be followed as to form its frame and content, the writer is totally free to go backwards or forwards.

Hyland (2003, p.76) stated that" despite considerable research into the writing process, we still do not have a comprehensive idea of how learners go about a writing task or how they learn to write". He goes on to say that" It is certain that much more research should be completed in order to offer learners better teaching. In reality, classes cannot wait until a perfect approach or method becomes available. Teachers including myself have to try to find more balanced and eclectic approaches which can motivate the students, and eventually improve their language abilities". The process approach has been generally accepted, and has been widely used, even though many researchers are still doubtful of its effectiveness.

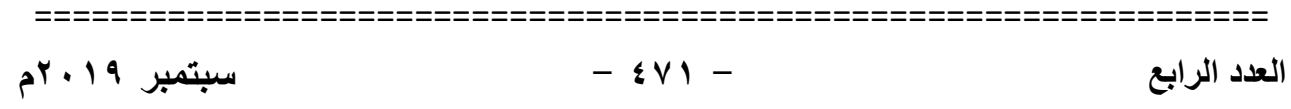




\section{Reading and Writing Skills' Integration: a Process Writing Based Approach (PWA)}

\section{Karima Mohamed El Sayed}

Cottrell (2003) indicates that the process of writing is linked to the development of other skills such as organization and reflection. With practice and understanding of academic conventions comes the ability to write more creatively. Also writing cannot be disengaged from other processes such as reflection, follow instructions, time management and investigation. As you can achieve your writing successfully, you become more aware of what is still required, you can be more flexible and innovative in your method to writing.

Grahan \& Perin (2015) analyzed the writing instructions during process of writing and concluded that writing strategies for planning, revising, and editing composition support students to manage both how to summarize and give instructional writing collaborative learning. Said that is likely to consider stages of writing process as main writing instructions contribute to spread collaborative writing environment, Moreover writing initials more complex tasks.

Prewriting can be considered as the secret key of achieving early stage of the writing process; simply it is the plan of starting point to write by stimulating ideas, words, terms and previous experience in writing then at last managing group of activities to fulfill the stage of prewriting perfectly. Extra sub activities could be 


\section{Reading and Writing Skills' Integration: a Process Writing Based Approach (PWA)}

\section{Karima Mohamed El Sayed}

brainstorming, clustering mapping, discussions, free writing and outlines. The writing process early stage is (brainstorming) which aims to prompt words and ideas, when you start to write many thoughts come to your mind but you have to decide which will be included in your text.Then you will frame definite outlines in order to plan your text. Johns et al (2006) demonstrated that prewriting is a recursive stage in the writing process that writers can find out, investigate, examine and generate the ideas they want to express and write about.

The way students manage to write down their ideas regardless about accuracy or correctness. Kingen (2000) stated that drafting works naturally without any concern of the mechanism of writing. Drafting is the transforming of the writer from based thought into reader-based text. He further stressed the view that these drafts are valuable to the students as to be considered, they are collections of thoughts for new directions. All writing drafts should be kept, not only while the writing is being developed, but also after it is completed.

The reviewing stage is the process of looking again and discovering new vision of the writing produced in drafting. It is the stage in which the writer corrects mechanical errors and realizes substantial changes in his/her writing (Grenville, 2001). Revising is

العدد الرابع




\section{Reading and Writing Skills' Integration: a Process Writing Based Approach (PWA)}

\section{Karima Mohamed El Sayed}

the stage where writers check that they have said what they wanted to say in a clear and appropriate way. Moreover, they stress that revising includes more than only checking spelling, grammar and punctuation, it also includes checking that content and purpose are clear and appropriate for the reader in the particular writing situation. According to Johnson (2008), revising is the heart of the writing, and it could be more productive of advanced final products if it includes input from teachers and/or peers, Truly peer review is the engine of class activity that enhances the students' ability to organize texts and also arise the student's self-awareness of reading.

Muncie (2000) defines editing as" putting the piece of writing into its final form." Prior to this stage, the students' main concern has not been local grammar errors or mechanics but content. Going into this stage, however, students eventually have time to polish- their writing by the correction of local errors and spelling. Atkinson (2003: p. 11) presents what writers should check in the final stage of their drafts as follows: "the order in which the information is presented, the layout, the spelling, punctuation, handwriting, choice of words and grammar". In the final stages, students should get distance from their composition and read it checking grammatical

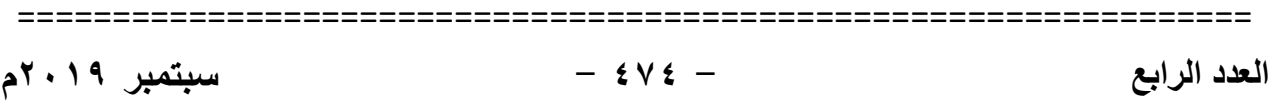




\section{Reading and Writing Skills' Integration: a Process Writing Based Approach (PWA)}

\section{Karima Mohamed El Sayed}

and mechanical errors. They can use not only grammar books and dictionaries but also peers and the teacher as resources in this stage.

The revised neat written text is made to be published to several channels (Ensio \& Boxeth, (2000); the publication channel could be audience, interview, journals, press, and bulletin. promoting students to publish their works to the audience peers, family, teachers, or other community in a meaningful form is the expected response in publishing stage. Also, inspires them to feel self-confidence.

Second Language writing tasks increase interest to the integration of reading writing skills, so the concern of reading writing interaction extended to students' studies of EFL as well as ESL. According to Plakans \& Gebril (2011)"an increasing number of writing programs and assessments are employing writing -fromsources tasks in which reading and writing are integrated." Many studies of reading writing relationship through a group of articles conducted by (Shanahan, 1990; Tierney \& Shanahan, 1991) listed that the 1980s decade of work and three principle instructions in L1 research on reading-writing integration." (1) shared processing and knowledge resources in reading and writing, (2) reading and writing as interaction, and (3) reading and writing to learn content. The first explains that common processing examines the overlay of 


\section{Reading and Writing Skills' Integration: a Process Writing Based Approach (PWA)}

\section{Karima Mohamed El Sayed}

processing skills. Students are examined in different reading abilities and writing abilities, then recorder the differences between the two. Results reveal significant differences between reading and writing. Second, "reading and writing as interaction" accents the term of discussion at a distance through the medium of the written text. Third, "learning content from reading and writing together" has not been enough elaborated and proved.

According to Grabe (2003) better readers tend to collect, organize and connect knowledge through their written texts; then resumed that students utilize the first reading to form a framework for summarizing when working with multiple texts. Plakans \& Gebril (2011) through a study investigates source use integrated second language writing tasks results showed while using source text many functions are employed to generate ideas about the topic. Plakans \& Gebril (2009) in a similar study summed that used source text writers has got high scores than indirect use source two groups.

According to various studies (e.g Chuenchaichon, 2001; Sanchez, 2009; Tuan, 2012), the integration of reading writing upgrades students' writing proficiency. This supports the active role of reading skills on the writing mastership, hence planning paraphrasing and summarizing based on the PWA leads to better

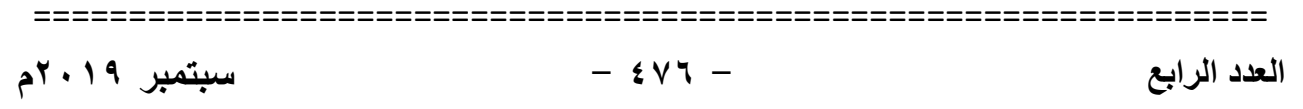




\section{Reading and Writing Skills' Integration: a Process Writing Based Approach (PWA)}

\section{Karima Mohamed El Sayed}

writing interpretation, not only but when the writer dialogues the written paraphrased or summarized text again they discover and explore the meaning.

Also a research conducted by Ibrahim (2006 p.4) reveals that the division between reading and writing hinders the development of language learning in general and writing ability in specific. Through a study by Keshta (2016) examined the impact of integrating reading and writing activities on Palestine Technical College Students' Paragraph Writing and Attitudes; and results revealed statically significant differences between two; control and experimental groups that reading and writing together get students promptly active to read and also highly engaged in the text writing process. Moreover students scored high motivation to read and read in order to comprehend then write.

Similarly, Al-Dosari (2016) attempted to investigate the influence of reading and writing integration on the quality of the written piece Al-Dosari concluded that there are direct positive effects which helped students to respond effectively on the learning literacy development and improvement of writing.

Writing can teach reading while pre analyzed lines tackling writing process as mentioned above the researcher explained how the

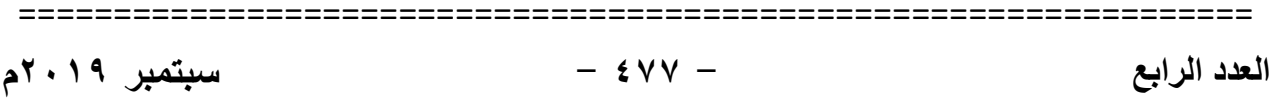




\section{Reading and Writing Skills' Integration: a Process Writing Based Approach (PWA)}

\section{Karima Mohamed El Sayed}

process of writing enhances learning of language starting from early main process stages end to sub ones; that writing inspires student to interpret through the text then share or publish it (via reading to audience) eventually reading polishes interaction and response to the written text. Kathleen (1999) noticed that when teaching both reading and writing separately they lose their effect to allow students respond to the text.

A study by Mohammed (2012) aimed to provide integrated reading writing grammar instructions to 44 experimental group students; results showed that they performed more significantly and effectively than the control group of 24 students. While reading Students try to check the writer concepts and beliefs then directly through writing they try reconstruct the writer meanings to the audience this process requires planning, checking, and revising reading times .

On the other hand, writers also attempt to achieve the writing process consistently through monitoring and organizing the text while composing from sources. Relating the different processes of reading to the writing's (Bearne, 2002) allow students to share readings of each other's drafts based on given content thus, they can response in advance. Such type of activity can be implemented at any of the stages of writing process as writers are to reflect whether

العدد الرابع




\section{Reading and Writing Skills' Integration: a Process Writing Based Approach (PWA)}

\section{Karima Mohamed El Sayed}

by paraphrasing or summarizing as the researcher suggests then peers, teacher or writer her/himself later can revise, edit or publish.

Similarly, (Tsai, 2006, p.2) expressed the idea to link courses on reading and writing in EFL college level.Tsai mentioned that teachers of English as a foreign or second language professionalized to teach reading and writing separately. Nevertheless, writing and reading share common features and learners are more likely to benefit from the teaching program that makes writing and reading activities go hand -in -hand in such a way that complete each other .Implementing this concept in real teaching conditions would not be a problematic challenge when EFL writing teachers consider students' requirements, are conscious of the advantages of the reading /writing linking, and wisely device teaching practices.

Developing learners' ability to write requires developing reading ability. According to (Ferris \& Hedgcock 2005), reading is the starting point of writing because through the acquired reading information learner attains the print-coded message and clues that demonstrate the written grammatical, lexical, semantically, pragmatic and rhetorical elements to form the meaningful text. Hirvela (2004) assured that reading provides writing through meaningful input. So the clear specific reading content forms the 


\section{Reading and Writing Skills' Integration: a Process}

\section{Karima Mohamed El Sayed}

\section{Writing Based Approach (PWA)}

writing text and platforms writers' attitudes through thinking and composing the text.

To conclude, the process writing approach includes five main stages (pre-writing- drafting - editing- revising and publishing). These stages can be integrated in reading writing activities that enhance both the two skills. The approach can provide EFL students with various chances to integrate between the two skills through its various stages that require practicing reading, comprehending the text then rewriting it using their own words and expressions. 


\section{Reading and Writing Skills' Integration: a Process Writing Based Approach (PWA)}

\section{Karima Mohamed El Sayed}

\section{References:}

Bae, J. (2011). Teaching Process Writing for Intermediate/Advanced Learners in South Korea, Master's Thesis, University of Wisconsin

Bearne, E. (2004) . The right thing to write, Keynote address presented at Write Voice Conference, Kent

Clandinin, D. \& Connelly, F. (2002) . Narrative, experience and the study of the curriculum', Cambridge Journal of Education, 20(3):241-53.

Cottrell, S. (2003). The study skills handbook, Palgrave Macmillan

Ferris, D \& Hdgcock, L. (2005). Treatment of Error. Ann Arbor: Michigan Series on Teaching Multilingual Writers, Hyland Print.

Ghaith, G., 2004. Writing. American University of Beirut. Beirut press

Hyland, Ken. Second Language Writing. 7th ed. New York: Cambridge UP, 2009. Print.

Grabe, E. (2003). Integrating the reading to write construct. Journal of English for academic purposes, Volume 7, Issue 3, Pp. 140-150

Grahan, S. \& Perin, H. (2015). Research based writing and the common core. The elementary school journal. Vol. 111 (4), pp. 1234

Hirvela, A. (2004). Connecting reading and writing in second language writing instruction. Ann Arbor, MI: University of Michigan Press.

Hyland, K. 2003. Genre-based pedagogies: A social response to process. Journal of Second Language Writing, 12: 17-29.

Kathleene, B. (1999). Historicizing writing assessment, College Composition and Communication, Vol. 50, No. 3, pp. 483-503 


\section{Reading and Writing Skills' Integration: a Process Writing Based Approach (PWA)}

\section{Karima Mohamed El Sayed}

Kingen, S. (2000). Teaching Language arts in middle schools. Psychology press

Mohamed, E. (2014). Writing to think, ESL Journal, 23 (43), pp. 34-56

Muncie, J. (2000). Using written teacher feedback in EFL composition classes. ELT Journal, 54(1): 47-53.

National Commission on Writing NCW (2003). America's Schools and Colleges writing, Retrieved: www.vantagelearning.com, Last visit $\{23-8-2019\}$

Plakans, L. \& Gebril, A. (2009). Investigating Source Use, Discourse Features, and Process in Integrated Writing Tests, Spaan Fellow Working Papers in Second or Foreign Language Assessment, pp. 47-84

Tsai, J. (2006). Connecting reading and writing in college EFL writing, The internet TESL Journal, Vol. XII, No. 12

Wooley, R. (2007). The effects of web-based paper review on student writing. Semantic Scholar, 23 (43), pp. 23-32 